\title{
An Economy-Wide Analysis of Trade Liberalization Impacts on Farm Household Income in Taiwan
}

\section{Yichieh Chen1, Hsing-Chun Lin², Sheng-Ming Hsu3 ${ }^{3}$ Yu-Chieh Chang4, Ruey-Wan Liou', Ching-Cheng Chang6, Shih-Hsun Hsu4*}

${ }^{1}$ Agricultural Technology Research Institute, Council of Agriculture, Taiwan

${ }^{2}$ Department of Applied Economics, National Chiayi University, Taiwan

${ }^{3}$ Department of Applied Economics, National Chung Hsing University, Taiwan

${ }^{4}$ Department of Agricultural Economics, National Taiwan University, Taiwan

${ }^{5}$ Statistical Office, Ministry of the Transportation and Communications, Taiwan

${ }^{6}$ Institute of Economics, Academia Sinica, Taiwan

Email:*m577@ntu.edu.tw

How to cite this paper: Chen, Y., Lin, H.-C., Hsu, S.-M., Chang, Y.-C., Liou, R.-W., Chang, C.-C., \& Hsu, S.-H. (2020). An Economy-Wide Analysis of Trade Liberalization Impacts on Farm Household Income in Taiwan. Modern Economy, 11, 1984-2005. https://doi.org/10.4236/me.2020.1112133

Received: October 9, 2020

Accepted: December 7, 2020

Published: December 10, 2020

Copyright $\odot 2020$ by author(s) and Scientific Research Publishing Inc. This work is licensed under the Creative Commons Attribution International License (CC BY 4.0).

http://creativecommons.org/licenses/by/4.0/ (c) (i) Open Access

\begin{abstract}
The impact of trade liberalization on Taiwan's agricultural sector has been an important issue in policy debates. In this study, a case study of cross-strait trade liberalization is conducted. With the elimination of all tariffs on bilateral trade between Chinese Mainland and Chinese Taipei, the SAM-based computable general equilibrium (CGE) model and database are applied to simulate the impacts of cross-strait trade liberalization on Taiwan's economy, agricultural output, non-agricultural income, farm household income and employment. Simulation results demonstrate that Taiwan's GDP will increase by $1.78 \%$, but total agricultural output will decrease by $0.9 \%$. For per farm household income, although agricultural income decreases by NTD 1648, non-agricultural income will increase by NTD 10,580. In total, per farm household income increases by NTD 8,932 with cross-strait trade liberalization. With trade liberalization as the engine of growth and a trade adjustment assistance mechanism at work, economic growth in Taiwan's agriculture may be maintained and in the long run, non-agricultural income and employment are likely to increase to provide a "safety net" for farm households.
\end{abstract}

\section{Keywords}

Trade Liberalization, Off-Farm Income, Computable General Equilibrium (CGE), Global Trade Analysis Project (GTAP) 


\section{Introduction}

In the process of economic development, the pace of agricultural development is relatively slower than other industries. The process of economic development differs from country/area to country/area. Due to limited natural resources, Taiwan relies on free trade to increase national income.

In recent decades, the major trends of commercialization, globalization, science and technology are all ongoing and interrelated. The impact of trade liberalization on Taiwan's agricultural sector has been an important issue in policy debates. Most of the debates focus on decreases in major indicators, e.g., total output value in production, food security, food self-sufficiency rates and agricultural income of farm households. Almost all of them neglect or ignore the potential increases in non-agricultural employment and income from local economic growth with trade liberalization.

According to the statistics of Food and Agriculture Organization of the United Nations (FAO), the proportion of the rural population in the national population is shown in Figure 1. The proportion in Chinese Taipei was $73.4 \%$ in 1950 and $21.8 \%$ in 2018 , while that in South Korea, Japan and the U.S. decreased from $78.6 \%, 46.6 \%$ and $35.8 \%$ to $18.5 \%, 8.4 \%$ and $17.7 \%$, respectively. This demonstrates that the reduction in the proportion of rural population is a normal trend of worldwide urbanization. The small rural population implies that the aging problem is becoming a serious issue.

Based on Table 1, one can see that the proportion of people over 65 has been increasing with each passing year among rural populations, a phenomenon most prominent in Japan at $61.08 \%$, followed by Korea at $49.10 \%$, and then Chinese Taipei at $27.89 \%$ and the proportion continues to increase each year.

Moreover, according to the data from the Directorate-General of Budget, Accounting and Statistics (DBAS), Taiwan's farm household income has increased from 108.2 thousand NTD to 1.09 million NTD since 1976, of which agricultural income has increased from 41.3 thousand NTD to 260.7 thousand NTD,

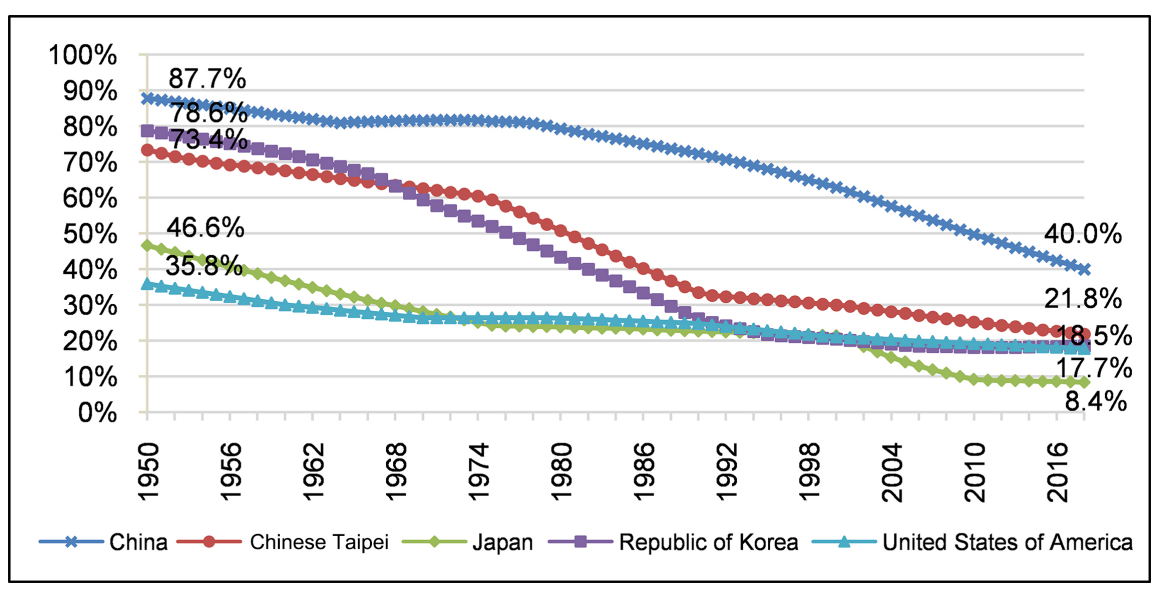

Figure 1. Proportion of rural population over national population. Source: Food and Agriculture Organization of the United Nations (accessed 25 Jul. 2020) and this study. 
and non-agricultural income has increased from 66.8 thousand NTD to nearly 838.6 thousand NTD. It is clear that a large part of the increase in farm household income is dependent on non-agricultural income, as shown in Figure 2. Also, according to the U.S. department of agriculture (USDA) research highlighted that the agricultural sector is much more dependent on the local economy than the local economy is on the agricultural sector (Blank, 2008).

Thus, how to stimulate the local economy through urbanization to create more non-agricultural job opportunities and subsequently increase farm household income is a noteworthy issue. The data above shows that the most important cause of a substantial change in rural employment, rural population structure, and farm household income is that the proportion of non-agricultural income in farm household income has increased.

Trade liberalization may increase gross domestic product (GDP), employment and income in non-agricultural sectors, but the agricultural sector may incur losses in employment and non-agricultural income. Sources of farm household

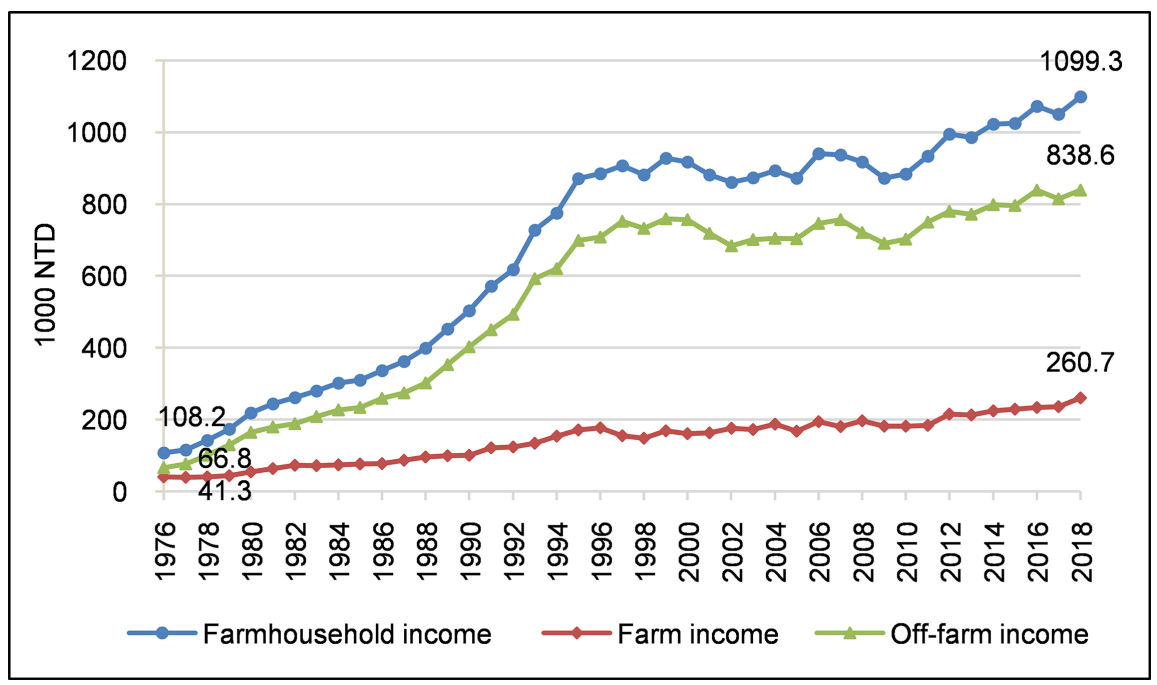

Figure 2. Composition of farm household income. Source: Directorate-General of Budget, Accounting and Statistics, Taiwan (accessed 25 Jul. 2020).

Table 1. Proportion of aged population (65 years and older) over rural population among major economies.

\begin{tabular}{ccccccccc}
\hline & 1980 & 1985 & 1990 & 1995 & 2000 & 2005 & 2010 & 2015 \\
\hline Chinese Mainland & $10.37 \%$ & $11.26 \%$ & $11.92 \%$ & $11.92 \%$ & $14.49 \%$ & $16.52 \%$ & $18.77 \%$ & $21.23 \%$ \\
Japan & $23.64 \%$ & $26.31 \%$ & $30.89 \%$ & $37.01 \%$ & $42.95 \%$ & $47.17 \%$ & $53.27 \%$ & $61.08 \%$ \\
Rep. of Korea & $11.20 \%$ & $13.67 \%$ & $18.01 \%$ & $23.39 \%$ & $29.29 \%$ & $37.12 \%$ & $43.18 \%$ & $49.10 \%$ \\
Chinese Taipei & $8.84 \%$ & $10.37 \%$ & $13.20 \%$ & $15.04 \%$ & $18.60 \%$ & $21.14 \%$ & $24.40 \%$ & $27.89 \%$ \\
USA & $21.90 \%$ & $23.73 \%$ & $25.60 \%$ & $26.65 \%$ & $26.99 \%$ & $27.84 \%$ & $30.52 \%$ & $34.44 \%$ \\
\hline
\end{tabular}

Source: The Database of Urban and Rural Population by Age and Sex, 1980-2015, The Population Division of the United Nations (accessed on October 31, 2020) and this study. 
income include agricultural income and non-agricultural income. Non-agricultural employment and income are closely related to the local economy. In this study, the social accounting matrix (SAM)-based GEMTEE (General Equilibrium Model for Taiwanese Economy and Environment) model-a computable general equilibrium (CGE) model that depicts the economy of Taiwan and its demographic structure over time-a flexible mechanism to reflect how fertility and population respond to income and demographic policies, is developed. The GEMTEE model is a CGE model derived from the Monash-type CGE model (Dixon \& Rimmer, 2002) and is calibrated with the 2011 SAM of Taiwan as the benchmark.

\section{Literature Review of the Relationship between Trade Liberalization and Agricultural Development, Employment of Farmers, Farm Income, etc.}

In the face of regionalization of the world economy, every country has engaged in bilateral, regional and multilateral trade agreements actively. The tariff reductions would benefit trade agreements. However, the appropriate response to a country's vulnerable industries (such as agriculture) should be considered.

Tura and Assefa (2017) described household in rural Ethiopia are diversifying activity both within agricultural and non-agricultural sectors. The study intended to show that the income obtained from non-farm activity and livestock business highly contributed for income inequality among the cereal crops producers. Irwin et al. (2010) studied rural development and the local economies in the U.S. and Canada. They believe that agricultural development has been an issue of general cross-sectoral equilibrium over the past century, which should be considered from a macroscopic perspective such as the interrelationship among industries. Leontief $(1936,1941,1953,1985)$ provided an "Input-output model" that could quantify the magnitude of interrelation among industries, which is a more comprehensive framework to analyze changes in industrial structure. The input-output table most widely used in the U.S. is the Impact Analysis for Planning which contains not only the country's information, but also state and provincial input-output tables for the preparation and evaluation of local economic development policies.

Due to the lack of a price component to the input-output table, the labor and wages are fixed and it is assumed that the supply of resources is unlimited in the absence of a pricing mechanism, which is the biggest drawback of the input-output model. Thus, the input-output model is more suitable for developing countries. For developed countries, due to limited resources, development has encountered bottlenecks, and there are problems with the efficiency and fairness of resource allocation. The CGE model is an applied microeconomics model (Dixon et al., 1992), an extension of Leontief's model. It includes price factor and the theory of limited resources into the input-output model, which expands the scope of application, so as to formulate and evaluate economic development 
policies more comprehensively.

Changes in the income of farm households apart from the effect of swaps of domestic industry that arise from the comparison of advantages and disadvantages in trade directly affect the value of agricultural products thereby causing additional losses to farm households. Changes in the income of farm households is a result of the comparative advantages and disadvantages in trade directly affect the value of the agricultural products, thus potentially leading to swaps of domestic industry. This causes additional losses to farm households.

The income of farm households can also be negatively affected by domestic price fluctuations, seasonality and disaster losses. Thus, the non-agricultural part of the income of farm households is particularly important. Reardon et al. (2001) observed Latin American countries and suggested that the agricultural sector's policies must be focused on increasing non-agricultural income in the context of regional trade liberalization. They proposed that in rural areas, we should not only develop agricultural economy. Instead, there should be multifaceted development in order to effectively reduce the risks associated with agricultural economy.

Mishra and Sandretto (2002) analyzed the income data of American farm households from 1933 to 1999, and showed that non-agricultural income can reduce changes in the income of farm households effectively. Haggblade et al. (2010) recommended that besides reducing risks in agricultural production practices, the development of a non-agricultural economy in rural areas will also contribute to rural economy development, as well as the elimination of poverty and inequality. Development of non-agricultural economy in rural areas and enhancing the non-agricultural part of the income of farm households could stimulate agricultural productivity indirectly. Berdegué et al. (2001) found that non-agricultural income could provide investment in equipment to improve agricultural productivity.

Ruttan (1955) believed that to increase the income of farm households, it is particularly important to increase job opportunities in the non-agricultural sector and activate the local economy. In the 1970s, American agricultural economists believed that "Rural area is more than just agriculture". Edwards (1981) considered that in the U.S., the rural or local economy is different from agricultural economy, and the growth of the rural economy and that of the agricultural economy cannot be considered equal. Furthermore, due to the improvement in agricultural technology, part of the agricultural labor force has been released to the non-agricultural sector, making the link between the agricultural sector and the non-agricultural sector much closer.

Agricultural economy now emphasizes economic diversity. Agricultural production occurs not only in rural development, but also throughout the services sector. The diversity of the rural economy is also associated with the value chain. Stabler and Olfert (2009) stated that agriculture inputs come from around the world, so the development of rural and urban areas becomes more rapid. Many 
rural residents can drive to work or shop in the city, and there is an abundance of medical care available in the city. Thus, the integration of urban and rural areas is getting improved.

Rural and agricultural policies should be differentiated. The viewpoint that development of rural economy "only" depends on agriculture or "majorly" relies on agriculture as the main driver should be amended. The interdependence between rural and agricultural policies should be taken seriously. One of the important ways to increase the income of farm households is to increase non-agricultural job opportunities, which need to be supported by a robust rural economy. The main instruments to promote rural development include investment in education, transportation, health, housing, and other construction in order to increase the attractiveness of rural areas (OECD, 2016). Damena and Habte (2017) studied indicates that nonfarm income has a role which is significant in maintaining household livelihood and to change their living standard such as enabling farmers to spend more on their basic needs.

\subsection{Taiwan's Agricultural Output}

The current situation of agricultural development in Taiwan is described by the main indicators of agriculture, such as Taiwan's agricultural total output value, total export value of agriculture, agricultural contribution to GDP, agricultural employment and agricultural income.

According to the Council of Agriculture (COA) and the DBAS, in 2018, Taiwan's overall output value was 40.75 trillion NTD, while agricultural output was 526 billion NTD, with a ratio of $1.29 \%$, as detailed in Table 2. Further analyzing Taiwan's agricultural output value during 1995-2018, one can see that the share in total output value shows a downward trend. However, following the 2008 financial crisis, Taiwan's total output fell by $8.92 \%$, agricultural production was not impacted as severely, only falling by $2.51 \%$. Precisely because the impact on total output was greater, once the economy recovered in 2010, total output increased by $19.15 \%$, such that agricultural output came to represent a noticeably smaller proportion of total output. Moreover, in response to issues resulting from global food price increases in 2008 and 2009 and in an effort to increase the food self-sufficiency, many initiatives were enacted to steadily increase food production, including the "Small Landowners and Large Tenant Farmers" initiative in 2009, the "Rice Field Multicultural Utilization Project" in 2011 and the "Adjusting the farming system to enrich the farmland project" in 2013.

\subsection{Taiwan's Agricultural Exports}

According to the COA and Customs Administration, in 2018, Taiwan's total export value was 334 billion USD, and the value of agricultural exports was 5463 million USD, which accounts for $1.64 \%$ of the total exports value, as detailed in Table 3. As we know, the value of agricultural exports showed an upward trend from 1995 to 2018, and its share in total tended to be stable after 2005. 
Table 2. Taiwan's agricultural output (1995-2018). Unit: million NTD.

\begin{tabular}{|c|c|c|c|c|c|}
\hline \multirow{2}{*}{ Year } & \multirow{2}{*}{$\begin{array}{l}\text { Agricultural } \\
\text { output }\end{array}$} & \multirow{2}{*}{ Total output } & \multirow{2}{*}{$\begin{array}{c}\text { Output share } \\
\text { of Agri. }\end{array}$} & \multicolumn{2}{|c|}{$\begin{array}{c}\text { The rate of change compared } \\
\text { to the previous year }\end{array}$} \\
\hline & & & & Agri. output & Total output \\
\hline 1995 & 411,139 & $15,999,195$ & $2.57 \%$ & - & - \\
\hline 1996 & 420,028 & $16,918,577$ & $2.48 \%$ & $2.16 \%$ & $5.75 \%$ \\
\hline 1997 & 379,028 & $18,307,716$ & $2.07 \%$ & $-9.76 \%$ & $8.21 \%$ \\
\hline 1998 & 376,652 & $19,332,090$ & $1.95 \%$ & $-0.63 \%$ & $5.60 \%$ \\
\hline 1999 & 390,936 & $20,074,574$ & $1.95 \%$ & $3.79 \%$ & $3.84 \%$ \\
\hline 2000 & 363,791 & $21,745,407$ & $1.67 \%$ & $-6.94 \%$ & $8.32 \%$ \\
\hline 2001 & 352,780 & $20,698,572$ & $1.70 \%$ & $-3.03 \%$ & $-4.81 \%$ \\
\hline 2002 & 350,478 & $21,954,637$ & $1.60 \%$ & $-0.65 \%$ & $6.07 \%$ \\
\hline 2003 & 357,885 & $23,286,278$ & $1.54 \%$ & $2.11 \%$ & $6.07 \%$ \\
\hline 2004 & 386,760 & $26,267,032$ & $1.47 \%$ & $8.07 \%$ & $12.80 \%$ \\
\hline 2005 & 382,726 & $27,543,546$ & $1.39 \%$ & $-1.04 \%$ & $4.86 \%$ \\
\hline 2006 & 376,994 & $29,750,175$ & $1.27 \%$ & $-1.50 \%$ & $8.01 \%$ \\
\hline 2007 & 389,129 & $32,132,831$ & $1.21 \%$ & $3.22 \%$ & $8.01 \%$ \\
\hline 2008 & 417,501 & $32,576,101$ & $1.28 \%$ & $7.29 \%$ & $1.38 \%$ \\
\hline 2009 & 407,021 & $29,669,541$ & $1.37 \%$ & $-2.51 \%$ & $-8.92 \%$ \\
\hline 2010 & 426,795 & $35,350,998$ & $1.21 \%$ & $4.86 \%$ & $19.15 \%$ \\
\hline 2011 & 475,732 & $36,954,978$ & $1.29 \%$ & $11.47 \%$ & $4.54 \%$ \\
\hline 2012 & 477,638 & $37,055,931$ & $1.29 \%$ & $0.40 \%$ & $0.27 \%$ \\
\hline 2013 & 482,493 & $37,605,629$ & $1.28 \%$ & $1.02 \%$ & $1.48 \%$ \\
\hline 2014 & 520,276 & $39,417,787$ & $1.32 \%$ & $7.83 \%$ & $4.82 \%$ \\
\hline 2015 & 503,580 & $38,074,608$ & $1.32 \%$ & $-3.21 \%$ & $-3.41 \%$ \\
\hline 2016 & 520,227 & $37,789,843$ & $1.38 \%$ & $3.31 \%$ & $-0.75 \%$ \\
\hline 2017 & 545,138 & $39,209,655$ & $1.39 \%$ & $4.79 \%$ & $3.76 \%$ \\
\hline 2018 & 526,008 & $40,750,588$ & $1.29 \%$ & $-3.51 \%$ & $3.93 \%$ \\
\hline
\end{tabular}

Source: Directorate-General of Budget, Accounting and Statistics; Council of Agriculture, Taiwan (accessed 31 Oct. 2020). 
Table 3. Taiwan's agricultural exports (1995-2018). Unit: million USD.

\begin{tabular}{cccc}
\hline Year & Agricultural export & Total export & Export share of Agri. \\
\hline 1995 & 5645 & 111,656 & $5.06 \%$ \\
2000 & 3279 & 148,316 & $2.21 \%$ \\
2005 & 3582 & 198,424 & $1.81 \%$ \\
2010 & 4027 & 274,596 & $1.47 \%$ \\
2015 & 4877 & 280,383 & $1.74 \%$ \\
2016 & 4673 & 279,191 & $1.67 \%$ \\
2017 & 4981 & 315,505 & $1.58 \%$ \\
2018 & 5463 & 334,026 & $1.64 \%$ \\
\hline
\end{tabular}

Source: Bureau of Foreign Trade; Council of Agriculture, Taiwan (accessed 25 Jul. 2020).

\subsection{Taiwan's Agricultural GDP}

Table 4 shows Taiwan's GDP and the contribution of agriculture to GDP from 1995 to 2018. Taiwan's agricultural contribution to GDP showed a significant downward trend, falling from $5.24 \%$ in 1995 to $1.99 \%$ in 2018 . After the accession to the WTO in 2002, the contribution of agriculture to GDP began to stabilize and remained at an average level of about $2.57 \%$.

\subsection{Taiwan's Agricultural Employment}

Table 5 shows the proportion of agricultural employment to total employment in Taiwan from 1995 to 2018. Change in the proportion of agricultural employment in Taiwan is similar to the contribution of agriculture to GDP. Before Taiwan's accession to the WTO, the proportion of agricultural employment continued to decrease from $10.55 \%$ in 1995 to $7.52 \%$ in 2001 . After 2002, the proportion of agricultural employment declined slowly, and maintained at about $5 \%$.

\subsection{Farm Household Income}

Table 6 shows the data of the average income of farm and non-farm households and the number of households from 1995 to 2018. Before 2000, the number of farm households and the average income of farm households show a downward trend; after joining the WTO in 2002, except for a slight decrease during the 2008 financial crisis, both of them showed a slight increase. However, the proportion of the agricultural household income accounting for the average non-farm household income per household remains at about $80 \%$, and we can see that the growth trend of farm households is similar to that of non-farm households. 
Table 4. Taiwan's agricultural GDP (1995-2018). Unit: million NTD.

\begin{tabular}{cccc}
\hline Year & GDP & GDP from Agri. contribution & GDP share of Agri. \\
\hline 1995 & $7,407,974$ & 387,897 & $5.24 \%$ \\
2000 & $9,863,229$ & 367,249 & $3.72 \%$ \\
2005 & $12,050,225$ & 337,701 & $2.80 \%$ \\
2010 & $14,889,912$ & 374,321 & $2.51 \%$ \\
2015 & $17,183,235$ & 362,488 & $2.11 \%$ \\
2016 & $17,555,268$ & 327,502 & $1.87 \%$ \\
2017 & $18,136,589$ & 354,585 & $1.96 \%$ \\
2018 & $18,634,482$ & 370,494 & $1.99 \%$ \\
\hline
\end{tabular}

Source: Bureau of Foreign Trade, Taiwan (accessed 25 Jul. 2020).

Table 5. Agricultural employment. Unit: 1000 people.

\begin{tabular}{cccc}
\hline Year & Total employment & Agricultural employment & Employment share of Agri. \\
\hline 1995 & 9,045 & 954 & $10.55 \%$ \\
2000 & 9,491 & 740 & $7.80 \%$ \\
2005 & 9,942 & 590 & $5.93 \%$ \\
2010 & 10,493 & 550 & $5.24 \%$ \\
2015 & 11,198 & 555 & $4.96 \%$ \\
2016 & 11,267 & 557 & $4.94 \%$ \\
2017 & 11,352 & 557 & $4.91 \%$ \\
2018 & 11,434 & 561 & $4.91 \%$ \\
\hline
\end{tabular}

Source: Council of Agriculture, Taiwan (accessed 25 Jul. 2020).

Table 6. Farm and non-farm average income per family and the number of households from 1995 to 2018.

\begin{tabular}{|c|c|c|c|c|c|}
\hline \multirow[b]{2}{*}{ Year } & \multirow[b]{2}{*}{$\begin{array}{l}\text { Farm families } \\
\text { (household) }\end{array}$} & \multirow[b]{2}{*}{$\begin{array}{l}\text { Total families } \\
\text { (household) }\end{array}$} & \multicolumn{2}{|c|}{ Average } & \multirow{2}{*}{$\begin{array}{l}\text { Average farm household } \\
\text { income over average } \\
\text { non-farm household } \\
\text { income per } \\
\text { household (\%) }\end{array}$} \\
\hline & & & $\begin{array}{c}\text { Farm } \\
\text { household's } \\
\text { income (NTD) }\end{array}$ & $\begin{array}{l}\text { Household } \\
\text { income } \\
\text { (NTD) }\end{array}$ & \\
\hline 1995 & 792,120 & $5,819,155$ & 871,082 & $1,029,053$ & $84.65 \%$ \\
\hline 2000 & 721,161 & $6,681,685$ & 917,623 & $1,139,336$ & $80.54 \%$ \\
\hline 2005 & 767,316 & $7,263,739$ & 872,677 & $1,133,642$ & $76.98 \%$ \\
\hline 2010 & 776,724 & $7,902,440$ & 884,547 & $1,123,761$ & $78.71 \%$ \\
\hline 2015 & 775,258 & $8,427,842$ & $1,025,699$ & $1,224,600$ & $83.76 \%$ \\
\hline 2016 & 775,472 & $8,519,450$ & $1,073,142$ & $1,253,389$ & $85.62 \%$ \\
\hline 2017 & 775,310 & $8,606,223$ & $1,050,176$ & $1,292,578$ & $81.25 \%$ \\
\hline 2018 & 775,070 & $8,690,801$ & $1,099,325$ & $1,310,447$ & $83.89 \%$ \\
\hline
\end{tabular}

Source: Council of Agriculture, Taiwan (accessed 25 Jul. 2020). 


\section{SAM-Based GEMTEE Database}

\subsection{Structure of 2011 Input-Output Table}

The input-output table demonstrates the structure of industries and the co-existing relationship among sectors (e.g., household, government, importer and exporter); it also shows the flows of income and human capital within the domestic economy system. The rows are the distribution of goods and the columns are the cost structure of industries or final demands (as shown in Figure 3).

\subsection{Establishment of Farm Household Income Database}

In this paper, a basic database is established by using the input-output table published by the DBAS. We divided income into farm household income and non-farm household income. The establishment of the farm household income database referenced the data of total farm household income published by the COA. According to the Agricultural Statistical Yearbook, sources of farm household income are divided into six categories: 1) compensation of employees; 2) entrepreneurial income; 3) property income; 4) imputed rent income; 5) current transfer receipts and 6) miscellaneous receipts.

According to the classification of the Agricultural Statistical Yearbook, "agricultural income" refers to "net primary agricultural income" and "net agricultural self-production income" in owners' total income, and others are "non-agricultural income." In this study, "non-agricultural income" is subdivided into "industrial income" and "non industrial income". "Industrial income" includes "compensation of employees" and "net non-agricultural business income". "Non-industrial income" includes "property income," "imputed rent income," "current transfer

\begin{tabular}{|c|c|c|c|c|c|c|c|}
\hline & & \multicolumn{6}{|c|}{ Absorption Matrix } \\
\hline & & 1 & 2 & 3 & 4 & 5 & 6 \\
\hline & & Producers & Investors & Household & Export & Other & $\begin{array}{l}\text { Change in } \\
\text { Inventories }\end{array}$ \\
\hline & Size & 1 & 1 & 1 & 1 & 1 & 1 \\
\hline Basic Flows & $\mathrm{C} \times \mathrm{S}$ & V1BAS & V2BAS & V3BAS & V4BAS & V5BAS & V6BAS \\
\hline Taxes & $\mathrm{C} \times \mathrm{S}$ & V1TAX & V2TAX & V3TAX & V4TAX & V5TAX & V6TAX \\
\hline Capital & 1 & V1CAP & \multicolumn{5}{|c|}{ I = Number of Industries, } \\
\hline Labour & $\mathrm{O}$ & V1LAB & \multicolumn{5}{|c|}{$C=$ Number of Commodities } \\
\hline Land & 1 & V1LND & \multicolumn{5}{|c|}{$\mathrm{O}=$ Number of Occupation Types, } \\
\hline Other Cost & 1 & V1OCT & \multicolumn{5}{|c|}{$\mathrm{S}=1$. Domestic 2. Imported. } \\
\hline
\end{tabular}

\begin{tabular}{|c|c|}
\cline { 2 - 2 } \multicolumn{1}{c|}{} & Joint Production Matrix \\
\hline Size & 1 \\
\hline C & MAKE \\
\hline
\end{tabular}

\begin{tabular}{|c|c|}
\cline { 2 - 2 } \multicolumn{1}{c|}{} & Import Duty \\
\hline Size & 1 \\
\hline C & VOTAR \\
\hline
\end{tabular}

Figure 3. The CGE core input-output database. Source: Dixon, et al. (1982). 
receipts", "miscellaneous receipts", etc. "Non-industrial income" is not included in the scope of this study. To sum up, the composition of agricultural and non-agricultural income in farm household income is shown in Figure 4.

In 2016, the average total income of farm households in Taiwan was 1073 thousand NTD, of which agricultural income was 234 thousand NTD, industrial income was 453 thousand NTD, and non-industrial income was 385 thousand NTD. The proportions of the three were $22 \%, 42 \%$, and $36 \%$ respectively over the past decade, as shown in Table 7. The share of the composition of farm household income in 2016 is shown in Figure 5 below. Other incomes include regular transfer income and other miscellaneous incomes. Regular transfer income also includes a variety of government subsidies (subsidies for farmers, cash assistance following natural disasters, subsidies for burials, maternity benefits, subsidies for crop shifting or allowing land to lay fallow, scholarships for the children of farmers, etc.) or prizes won from government lotteries, etc. Income originating from private sources includes income from private donations, cash gifts, or private relief funds, etc. Other income comes from social insurance or corporate assistance, etc. With regard to miscellaneous incomes, this may include income farmers have earned from selling waste materials, old newspapers, the occasional collection of forestry products, or income from hook and line or mass fishing, and income of less than 20,000 NTD in a year from selling scrapped household equipment.

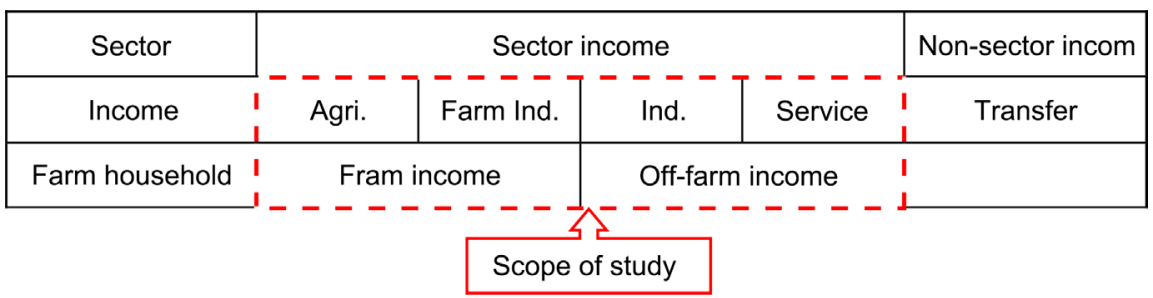

Figure 4. Structure of farm household income. Source: this study.

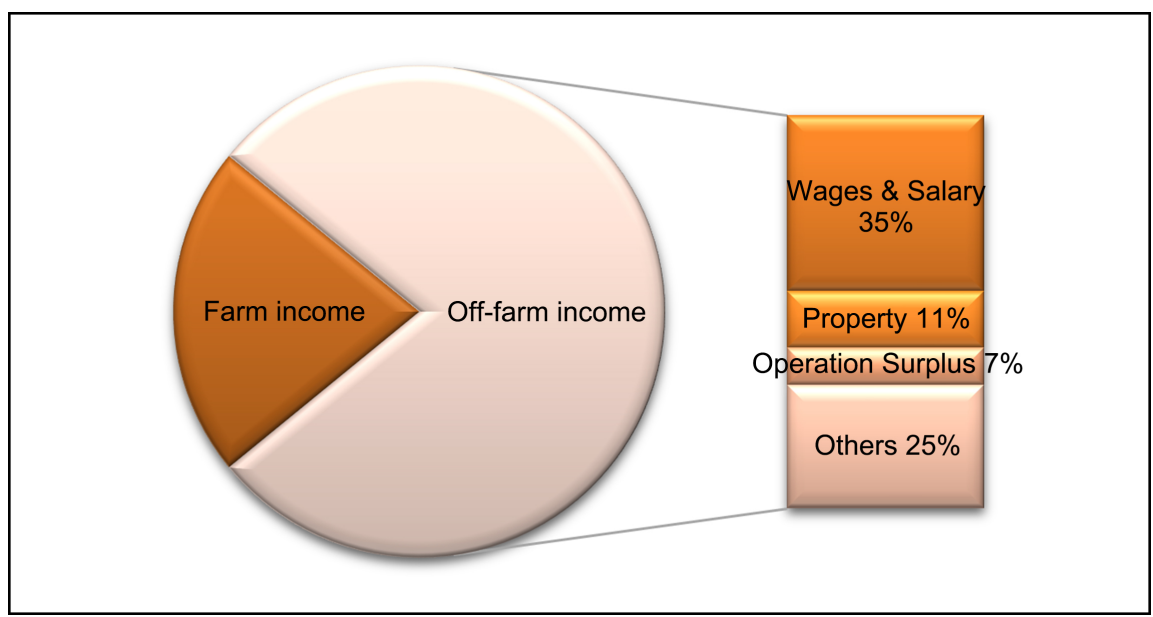

Figure 5. Share of the composition of farm household income in 2016. Source: Taiwan's Agricultural Statistical Yearbook (2016). 
Table 7. Composition of average farm household total income. Unit: NTD.

\begin{tabular}{|c|c|c|c|c|c|c|c|c|}
\hline \multirow[b]{2}{*}{ Year } & \multirow{2}{*}{$\begin{array}{l}\text { Average farm } \\
\text { household } \\
\text { total income }\end{array}$} & \multirow{2}{*}{$\begin{array}{l}\text { Farm } \\
\text { income }\end{array}$} & \multicolumn{2}{|c|}{ Off-farm income } & \multirow{2}{*}{$\begin{array}{l}\text { Average farm } \\
\text { household } \\
\text { total income }\end{array}$} & \multirow{2}{*}{$\begin{array}{l}\text { Farm } \\
\text { income }\end{array}$} & \multicolumn{2}{|c|}{ Off-farm income } \\
\hline & & & $\begin{array}{l}\text { Industrial } \\
\text { income }\end{array}$ & $\begin{array}{l}\text { Non-industrial } \\
\text { income }\end{array}$ & & & $\begin{array}{l}\text { Industrial } \\
\text { income }\end{array}$ & $\begin{array}{l}\text { Non-industrial } \\
\text { income }\end{array}$ \\
\hline 2003 & 873,901 & 172,414 & 407,117 & 294,370 & $100 \%$ & $20 \%$ & $47 \%$ & $34 \%$ \\
\hline 2004 & 893,124 & 187,758 & 404,754 & 300,612 & $100 \%$ & $21 \%$ & $45 \%$ & $34 \%$ \\
\hline 2005 & 872,677 & 168,694 & 393,835 & 310,148 & $100 \%$ & $19 \%$ & $45 \%$ & $36 \%$ \\
\hline 2006 & 941,160 & 195,137 & 426,043 & 319,980 & $100 \%$ & $21 \%$ & $45 \%$ & $34 \%$ \\
\hline 2007 & 937,053 & 180,562 & 407,704 & 348,787 & $100 \%$ & $19 \%$ & $44 \%$ & $37 \%$ \\
\hline 2008 & 917,705 & 196,919 & 376,590 & 344,196 & $100 \%$ & $21 \%$ & $41 \%$ & $38 \%$ \\
\hline 2009 & 872,668 & 182,102 & 349,131 & 341,436 & $100 \%$ & $21 \%$ & $40 \%$ & $39 \%$ \\
\hline 2010 & 884,547 & 182,160 & 392,921 & 309,466 & $100 \%$ & $21 \%$ & $44 \%$ & $35 \%$ \\
\hline 2011 & 933,785 & 183,948 & 432,052 & 317,785 & $100 \%$ & $20 \%$ & $46 \%$ & $34 \%$ \\
\hline 2012 & 995,645 & 215,795 & 434,504 & 345,346 & $100 \%$ & $22 \%$ & $44 \%$ & $35 \%$ \\
\hline 2013 & 985,343 & 213,800 & 419,224 & 352,318 & $100 \%$ & $22 \%$ & $43 \%$ & $36 \%$ \\
\hline 2014 & $1,023,248$ & 224,859 & 440,669 & 357,719 & $100 \%$ & $22 \%$ & $43 \%$ & $35 \%$ \\
\hline 2015 & $1,025,699$ & 229,860 & 441,065 & 354,773 & $100 \%$ & $22 \%$ & $43 \%$ & $35 \%$ \\
\hline 2016 & $1,073,142$ & 234,067 & 453,971 & 385,104 & $100 \%$ & $22 \%$ & $42 \%$ & $36 \%$ \\
\hline
\end{tabular}

Source: Taiwan's Agricultural Statistical Yearbook (2016).

The estimation of total farm household income in the model's base year (2011) refers to average farm household income in 2011 (933 thousand NTD) and total number of farm households (777,473 households). Taiwan's estimated total farm household income is 726 billion NTD, where agricultural income is 143 billion NTD, industrial income is 336 billion NTD, and non-industrial income is 247 billion NTD.

In this paper, the impact of cross-strait trade liberalization on farm households' income is analyzed. We progress a mechanism of impact on price and production of import and export commodities by decreasing tariffs of each industry to zero. We divided industry sectors into agriculture, agro-industry, industry and the service sector. In the income of farm households, the income from industry sectors is divided into "agricultural income" and "industrial income". We assume that agricultural income comes from the "agriculture" and "agro-industry" sectors, and industrial income comes from the "industry" and "service" sectors. In addition, the SAM-based GEMTEE model which includes transfer income and expenditure of the social accounting accounts is adopted. Therefore, the "non-industrial income" in the income of farm households including "property income", "imputed rent income", "current transfer receipts", 
and "miscellaneous receipts" will be endogenously solved in the model.

According to categories in study, total national income is 7295 billion NTD, where 136 billion NTD from the agricultural sector, 95 billion NTD from the agro-industry sector, 1352 billion NTD from the industry sector, and 5712 billion NTD from the service sector. We assume that all income from the agricultural sector in farm household's agricultural income, and the remaining 6.9 billion NTD is assumed to come from the agro-industry sector; whereas the farm household's non-agricultural income is estimated from sector salary and the number of households in the industry and service sectors, according to the household income and expenditure survey. The estimated results are shown in Table 8 .

\section{Assessment of the Impact of Cross-Strait Trade Liberalization on Agriculture Development and Income of Farm Households}

Considering the current development of the domestic and foreign economic environments and cross-strait relationships, cross-strait trade liberalization is absolutely necessary and important.

\subsection{Operation of GTAP and GEMTEE Model}

In this study, an integrated model of empirical simulation operation is formed by combining multi-national and single country CGE models using the soft link method. In the setting of policy simulation scenarios, this study refers to the "ex ante" analytical method mentioned by Dixon and Rimmer (2002), Lin et al. (2013) and Lin et al. (2015). First, we take cross-strait trade liberalization as the basic scenario, reducing tariffs on all commodities between Chinese Taipei and Chinese Mainland to zero. The price change between international imports and exports is calculated using the GTAP model (Hertel, 1997). Thus, under this framework, the impact of cross-strait trade liberalization on Taiwan's agricultural sector and farm household income is simulated using GEMTEE model. The framework for simulation is shown in Figure 6.

GEMTEE was jointly developed by the Center for Sustainable Science of the Academia Sinica and the Australian Bureau of Agriculture, Resources and Economics (ABARES) (Chang et al., 2018). It is based on the Monash dynamic computable general equilibrium model, and expanded through investment and population dynamics mechanisms (Dixon et al., 1982, Dixon \& Parmenter, 1996; Dixon \& Rimmer, 2002).

Based on the ninth edition GTAP database (Aguiar et al., 2016), the calculated level of trade distortion between Chinese Taipei and Chinese Mainland is shown in Table 8. Using the GTAP model, the impact on import and export prices of Taiwan's current commodities under the condition of full tariff concessions between Chinese Taipei and Chinese Mainland, excluding non-tariff barriers, is estimated, with the estimated result shown in Table 9. 


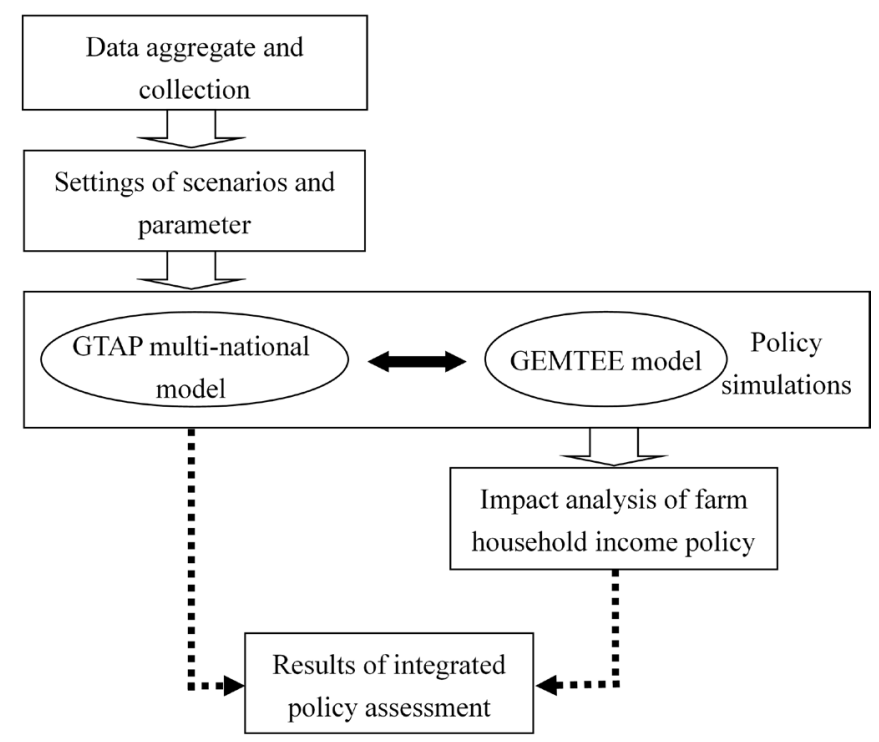

Figure 6. Functions and connection between GTAP and GEMTEE models. Source: this study.

Table 8. Composition of total national income in 2011. Unit: million NTD.

\begin{tabular}{cccccc}
\hline Sector & Agriculture & Agro-industry & Industry & Service & Total \\
\hline Total income & 136,068 & 95,146 & $1,352,609$ & $5,712,053$ & $7,295,876$ \\
Farm income & 136,068 & 6,947 & 64,314 & 271,595 & 478,923 \\
Off-farm income & - & 88,199 & $1,288,295$ & $5,440,458$ & $6,816,953$ \\
\hline
\end{tabular}

Source: The Report on 2011 Input-Output Tables, Taiwan and this study.

Table 9. Level of trade distortion between Chinese Taipei and Chinese Mainland.

\begin{tabular}{ccc}
\hline Sector & $\begin{array}{c}\text { Level of trade distortion } \\
\text { in Chinese Taipei }\end{array}$ & $\begin{array}{c}\text { Level of trade distortion } \\
\text { in Chinese Mainland }\end{array}$ \\
\hline Agriculture & $3.47 \%$ & $15.60 \%$ \\
Agro-industry & $7.66 \%$ & $11.34 \%$ \\
Industry & $3.03 \%$ & $4.72 \%$ \\
Service & $0.00 \%$ & $0.00 \%$ \\
\hline
\end{tabular}

Source: This study.

The simulation results in Table 10 show that import price of domestic agricultural products decreases by $1.77 \%$, while export price by $1.65 \%$. Import price of the agro-processing industry decreases by $1.64 \%$ and you can see a reduction of $0.97 \%$ in export price. For the industrial products, import price decreases by $1.98 \%$ while export price increases by $10.67 \%$. There is a $1.30 \%$ decrease in import price and a $0.68 \%$ increase in export price for the service sector. 


\subsection{Results of the Impact of Cross-Strait Trade Liberalization on Taiwan's Agricultural Development and Income of Farm Households}

In general, signings of regional trade agreements (RTAs) can enhance the connection between domestic and international markets through trade liberalization. The removal of trade barriers between two regions can improve the circulation of commodities. Due to a rise in the scale of economy and improved efficiency of resources utilization, the national economic welfare will be enhanced.

There are three scenarios in this study. Scenario 1 calibrates the model to 2016 and maintains the current cross-strait trade relationship situation. Scenario 1 does not consider the elimination of trade distortions and changes in technology. All of the simulation results are calibrated by the model. There is no policy shock in Scenario 1. Scenario 2 depicts a full liberalization in the industrial and services sectors, but with some trade restrictions in agriculture. Scenario 3 simulates that in 2016, both regions have reduced tariffs on all commodities to zero. The design of these simulation scenarios is shown in Table 11.

From GEMTEE baseline forecasting solved using GEMPACK (Harrison \& Pearson, 1996). In Scenario 2, for the agricultural sector, since the elimination of cross-strait tariff barriers excludes 830 kinds of agricultural products, both import and export price of agricultural products are reduced. Because of the lower prices of agricultural products in Chinese Mainland, the agricultural production value in Chinese Taipei will decrease from 520.9 billion NTD to 516.5 billion NTD, a decline of $0.84 \%$. Yet a complete elimination of cross-strait tariff barriers will reduce the agricultural production value in Chinese Taipei to 511.8 billion NTD, a reduction of $0.91 \%$. These results are shown in Table 12 .

Table 10. Estimated results of the impact on import and export price of Taiwan's current commodities.

\begin{tabular}{ccc}
\hline Sector & $\begin{array}{c}\text { Import prices of domestic } \\
\text { products }\end{array}$ & $\begin{array}{c}\text { Export prices of domestic } \\
\text { products }\end{array}$ \\
\hline Agriculture & $-1.77 \%$ & $-1.65 \%$ \\
Agro-industry & $-1.64 \%$ & $-0.97 \%$ \\
Industry & $-1.98 \%$ & $10.67 \%$ \\
Service & $-1.30 \%$ & $0.68 \%$ \\
\hline
\end{tabular}

Source: This study.

Table 11. Simulation scenarios design.

\begin{tabular}{cccc}
\hline Scenarios & Scenario 1 & Scenario 2 & Scenario 3 \\
\hline Trade relationship & $\begin{array}{c}\text { Keep current } \\
\text { situation }\end{array}$ & $\begin{array}{c}\text { Full liberalization in } \\
\text { industrial and services } \\
\text { but with some trade } \\
\text { restriction in agriculture }\end{array}$ & $\begin{array}{c}\text { Reduce tariffs of all } \\
\text { commodities to zero }\end{array}$ \\
& &
\end{tabular}

Source: This study. 
Table 12. Impact of cross-strait trade liberalization on Taiwan's agricultural production value. Unit: million NTD.

\begin{tabular}{ccc}
\hline Scenario & Agricultural production value & Percentage change (\%) \\
\hline Scenario 1 & 520,957 & $0 \%$ \\
Scenario 2 & 516,575 & $-0.84 \%$ \\
Scenario 3 & 511,874 & $-0.91 \%$ \\
\hline
\end{tabular}

Source: This study. Note: The production value in Scenario 1 refers to 2016.

For the impact on the income of farm households, results are calibrated by the model in Scenario 1 as shown in Table 13. The total national income of farm households is 478.9 billion NTD, of which 136.1 billion NTD comes from agricultural sector, 6.9 billion NTD comes from agro-industry sector, 64.3 billion NTD comes from industry sector, and 271.6 billion NTD comes from service sector.

In scenario 2, income of farm households from the agricultural sector is 135 billion NTD, a decrease of $0.76 \%$ compared with Scenario 1, while the income from agro-industry is 7.1 billion NTD, an increase of $2.19 \%$. Non-agricultural income from the industry and service sectors is 67.5 billion NTD and 275.2 billion NTD, an increase of $4.9 \%$ and $1.36 \%$, respectively. The total income of farm households in Scenario 2 is 484.9 billion NTD, an increase of $1.36 \%$ compared with Scenario 1.

For Scenario 3, income of farm households from the agricultural sector is 134.8 billion NTD, a decline of $0.9 \%$ compared with Scenario 1 . Meanwhile, income from the agro-industry sector is 7.1 billion NTD, an increase of $2.21 \%$. Non-agricultural income from the industry and service sectors is 67.5 billion NTD and 275.3 billion NTD, an increase of $4.91 \%$ and $1.37 \%$, respectively. The total income of farm households in Scenario 3 is 484.7 billion NTD, an increase of $1.21 \%$ compared with Scenario 1. In addition, the overall impact on GDP increases by $1.779 \%$ in Scenario 2 compared with Scenario 1, while it increases by $1.776 \%$ in Scenario 3.

From the perspective of the composition of farm household income (as shown in Table 14), the proportions of agriculture, agro-industry, industry and service sectors in Scenario 1 are $28.41 \%, 1.45 \%, 13.43 \%$ and $56.71 \%$, respectively, while those of each sector in Scenario 2 are 27.85\%, 1.46\%, 13.91\% and 56.77\%, respectively, and those in Scenario 3 are $27.82 \%, 1.46 \%, 13.92 \%$ and $56.80 \%$, respectively. According to the trend in results, in Scenario 2, the proportion of farm household income from agriculture decreases by $0.56 \%$, that from agro-industry increases by $0.01 \%$, that from industry increases by $0.48 \%$, and that from service sector increases by $0.06 \%$. In Scenario 3, although the proportion of farm household income from the agricultural sector is reduced by $0.59 \%$, the proportions from the agro-industry, industry, and service sectors increase by $0.01,0.49$, and 0.09 percentage points respectively. 
Table 13. Impact of cross-strait trade liberalization on the composition change in farm household income and rates of change. Units: million NTD; \%.

\begin{tabular}{|c|c|c|c|c|c|c|}
\hline \multirow{2}{*}{ Scenarios } & \multicolumn{4}{|c|}{ Sectors } & \multirow{2}{*}{ Total } & \multirow{2}{*}{$\begin{array}{l}\text { Rates of } \\
\text { change }\end{array}$} \\
\hline & Agriculture & Agro-industry & Industry & Service & & \\
\hline Scenario 1 (baseline) & 136,068 & 6947 & 64,314 & 271,595 & 478,923 & \\
\hline Scenario 2 & 135,036 & 7099 & 67,462 & 275,290 & 484,886 & $1.779 \%$ \\
\hline Scenario 3 & 134,841 & 7100 & 67,471 & 275,326 & 484,738 & $1.776 \%$ \\
\hline Scenario $2 /$ Scenario 1 & $99.24 \%$ & $102.19 \%$ & $104.90 \%$ & $101.36 \%$ & $101.25 \%$ & \\
\hline Scenario $3 /$ Scenario 1 & $99.10 \%$ & $102.21 \%$ & $104.91 \%$ & $101.37 \%$ & $101.21 \%$ & \\
\hline
\end{tabular}

Source: This study.

Table 14. Impact of cross-strait trade liberalization on the composition of farm household income. Unit: \%.

\begin{tabular}{cccccc}
\hline Scenarios & Agriculture & Agro-industry & Industry & Service & Total \\
\hline Scenario 1 & $28.41 \%$ & $1.45 \%$ & $13.43 \%$ & $56.71 \%$ & $100.00 \%$ \\
Scenario 2 & $27.85 \%$ & $1.46 \%$ & $13.91 \%$ & $56.77 \%$ & $100.00 \%$ \\
Scenario 3 & $27.82 \%$ & $1.46 \%$ & $13.92 \%$ & $56.80 \%$ & $100.00 \%$ \\
Sercentage points $\quad$ Scenario 2 to 1 & -0.56 & +0.01 & +0.48 & +0.06 \\
\hline
\end{tabular}

Source: this study.

In Scenarios 2 and 3, the increase in the total farm household income illustrates that the proportion of farm household income has transferred from the agricultural sector to the agro-industry sector, as well as to the industry and service sectors. By comparing results in Scenario 2 and Scenario 3, we can find that full liberalization would decrease the proportion of farm household income from the agricultural sector and increase the proportions from the agro-industry, industry, and service sectors.

The results of the impact of cross-strait liberalization on domestic employment are shown in Table 15. In Scenario 1, the calibrated number of agricultural employees is 542,001 in 2016. The numbers of agricultural employees in Scenario 2 and Scenario 3 are 522,551 and 517,962, respectively. The proportion of agricultural employment is the highest (4.95\%) in Scenario 1, while that in Scenario 3 is the lowest (4.67\%).

To estimate Taiwan's average income of farm households, we first assume that the number of farm households and the amount of non-agricultural income from the non-industrial sector in 2016 is the same as in 2013, which is 780,307 households and NTD 352,319, respectively. Furthermore, we classified the estimated results into agricultural and non-agricultural income according to the definition of the COA. Estimated results of average farm household income in 
Table 15. Impact of cross-strait trade liberalization on domestic employees. Units: People; \%.

\begin{tabular}{cccc}
\hline Scenarios & $\begin{array}{c}\text { Agricultural } \\
\text { employees }\end{array}$ & Total employees & $\begin{array}{c}\text { Proportion of } \\
\text { agro.-employment }\end{array}$ \\
\hline Scenario 1 & 542,001 & $10,946,108$ & $4.95 \%$ \\
Scenario 2 & 522,551 & $11,100,635$ & $4.71 \%$ \\
Scenario 3 & 517,962 & $11,097,430$ & $4.67 \%$ \\
\hline
\end{tabular}

Source: This study.

Table 16. Impact of cross-strait trade liberalization on Taiwan's average farm household income. Units: NTD; \%.

\begin{tabular}{|c|c|c|c|c|}
\hline \multirow{2}{*}{ Sources of income } & \multirow{2}{*}{ Farm income } & \multicolumn{2}{|c|}{ Off-farm income } & \multirow{2}{*}{ Total } \\
\hline & & Ind. income & Non-Ind. income & \\
\hline Scenario 1 & 219,670 & 515,956 & & $1,087,945$ \\
\hline Scenario 2 & 218,855 & 526,467 & 352,319 & $1,097,641$ \\
\hline Scenario 3 & 218,022 & 526,536 & & $1,096,876$ \\
\hline Proportion of income & Farm income & \multicolumn{2}{|c|}{ Off-farm income } & Total \\
\hline Scenario 1 & $20.19 \%$ & \multicolumn{2}{|c|}{$79.81 \%$} & $100.00 \%$ \\
\hline Scenario 2 & $19.90 \%$ & \multicolumn{2}{|c|}{$80.10 \%$} & $100.00 \%$ \\
\hline Scenario 3 & $19.88 \%$ & \multicolumn{2}{|c|}{$80.12 \%$} & $100.00 \%$ \\
\hline
\end{tabular}

Source: This study.

three scenarios are 1.08 million NTD, 1.09 million NTD, and 1.09 million NTD, respectively. We found that the income of farm households is higher in the case of trade liberalization.

In addition, we found that the proportion of agricultural income is the highest in Scenario 1 (20.19\%) and the lowest in Scenario 3 (19.88\%), while the proportion of non-agricultural income is the highest in Scenario $3(80.12 \%)$ and the lowest in Scenario 1 (79.81\%). This shows that the higher the degree of agricultural liberalization, the lower the proportion of agricultural income. However, non-agricultural income will benefit from trade liberalization, as detailed in $\mathrm{Ta}$ ble 16.

\section{Conclusion}

Taiwan is an export-oriented economy, with exports accounting for over 70\% of her GDP. The trade surplus has become the main export momentum of Taiwan's economic growth. With the global trend of regional economic integration, many countries actively participate in having actively signed RTAs and bilateral free trade agreements (FTAs), which helps reduce tariff and non-tariff barriers to the free flow of goods, services, and factors of production among each other. 
Since 2010, the successive establishment of free trade zones, like the ASEAN and CPTPP, etc., has brought significantly impact on Taiwan's industrial competitiveness. With free trade agreements signed, as an economy lacking the advantages of natural resources, we must gradually open up agricultural borders which will inevitably affect farmers' livelihoods and rural residents too.

This paper analyzes the impact of Taiwan's agricultural development due to cross-strait trade liberalization. Through the simulation analysis, we realize under the cross-strait exchanges and cooperation in trade, agriculture will be positively affected under the driving force of other industries. In addition, from the perspective of farm households' income, we analyze the impact of cross-strait trade liberalization on agricultural income and non-agricultural income, and investigate the importance of free trade to non-agricultural income.

There are three scenarios in this paper, including a baseline scenario, a cross-strait zero-tariff policy on all goods except for Taiwan's 830 agricultural products, and a cross-strait zero-tariff policy on all goods. Under the state of reserving 830 agricultural products to be not-open to trade, the total output value of agriculture will be reduced from 520.9 billion NTD to 516.5 billion NTD, a decrease of $0.84 \%$. If the cross-strait tariff barriers are completely eliminated, then the total output value will be reduced to 511.8 billion NTD, a decrease of $0.91 \%$.

From the composition of farm household income, in the case that 830 kinds of agricultural products are reserved not-open, the changes in the proportion of the income of farm households coming from agriculture, agro-industry, industry and service sectors are $-0.56 \%, 0.01 \%, 0.48 \%$ and $0.06 \%$, respectively; after the cross-strait trade liberalization, the changes in the proportion from agriculture, agro-industry, industry and service sectors are $-0.59 \%, 0.01 \%, 0.49 \%$ and $0.09 \%$, respectively. This shows that the proportion of the income of farm households is transferred to the agro-industry, industry and service sectors. Meanwhile, complete trade liberalization will lower the proportion of agricultural income, and raise the proportion of non-agricultural income which is composed of income from the agro-industry, industry and service sectors.

As for the estimation of the impact of cross-strait trade liberalization on agricultural employment, the baseline scenario estimates 542 thousand people are engaged in agriculture, accounting for $4.95 \%$ of total employment. The scenario of limited cross-strait trade liberalization estimates that 522 thousand people are engaged in agriculture. The scenario of complete cross-strait trade liberalization estimates that 517 thousand people are engaged in agriculture, accounting 4.67\% of total employment, which is the lowest proportion among the three scenarios.

Finally, the farm household income (per household) in 2016 is estimated based on the data of 780,000 farm households and non-industrial income of NTD 350,000.The income of farm households is highest in a scenario of limited cross-strait trade liberalization. Considering income sources in each scenario proportionally, we find that allowing more trade in agricultural products will 
reduce the proportion of agricultural income, but due to the benefits of free trade, non-agricultural income will increase, which helps to increase the income of Taiwan's farm households.

The analysis conducted in this study is based on the agricultural sector as a whole. The impact of cross-strait trade liberation on agricultural production and the income of farmers differs depending on the degree to which individual industries have opened up. In future research, data must be collected on individual farming industries (e.g., the rice or vegetable industries) for which further analysis may be conducted on the impact on farm households using the same overall framework. Moreover, this study uses static analysis to consider the impact of differing levels of trade liberalization on agricultural development and the income of farm households. In the future, the author hopes to incorporate dynamic research practices to provide baseline forecasting and analyze the impact of trade liberalization on Taiwan's agricultural sector and farm household income.

\section{Acknowledgements}

This research is supported by the Mainland Affairs Council of Taiwan. A preliminary draft of this paper was accepted for presentation at the $19^{\text {th }}$ Annual Conference on Global Economic Analysis, The World Bank, Washington DC, USA, 15-17 June, 2016. The authors would like to thank two anonymous Journal reviewers for their helpful comments.

\section{Conflicts of Interest}

The authors declare no conflicts of interest regarding the publication of this paper.

\section{References}

Aguiar, A., Narayanan, B., \& McDougall, R. (2016). An Overview of the GTAP 9 Data Base. Journal of Global Economic Analysis, 1, 181-208. https://doi.org/10.21642/JGEA.010103AF

Berdegué, J. A., Ramırez, E., Reardon, T., \& Escobar, G. (2001). Rural Nonfarm Employment and Incomes in Chile. World Development, 29, 411-425. https://doi.org/10.1016/S0305-750X(00)00102-9

Blank, S. C. (2008). The Economics of American Agriculture: Evolution and Global Development. New York: M.E. Sharpe Inc.

Chang, C. C., Hsu, H. S., Lin, H. C., Lee, D. H., Chen, C. C., \& Wu, C. H. (2018). Enhanced GEMTEE (General Equilibrium Model for Taiwan Economy and Environment) for IAM Framework-An Integrated Computable General Equilibrium Model and Database for Appraising Policies toward Sustainable Development. A Progress Report for Sustainability Science Research Program, Academia Sinica, Taiwan.

Damena, A., \& Habte, D. (2017). Effect of Non-Farm Income on Rural Household Livelihood: A Case Study of Moyale District Oromia Regional State, Ethiopia. American Scientific Research Journal for Engineering, Technology, and Sciences, 33, 10-36.

Dixon, P. B., \& Parmenter, B. R. (1996). Chapter 1: Computable General Equilibrium 
Modelling for Policy Analysis and Forecasting. In H. M. Amman, D. A. Kendrick, \& J. Rust (Eds.), Handbook of Computable Economics (Vol. 1, pp. 3-85). Amsterdam: North Holland. https://doi.org/10.1016/S1574-0021(96)01003-9

Dixon, P. B., \& Rimmer, M. T. (2002). Dynamic General Equilibrium Modelling for Forecasting and Policy: A Practical Guide and Documentation of MONASH, Contributions to Economic Analysis. Amsterdam: North Holland.

Dixon, P. B., Parmenter, B. R., Powell, A. A., \& Wilcoxen, P. J. (1992). Notes and Problems in Applied General Equilibrium Economics. Amsterdam: North-Holland.

Dixon, P. B., Parmenter, B. R., Sutton, J. M., \& Vincent, D. P. (1982). ORANI: A Multisectoral Model of the Australian Economy. Amsterdam: North-Holland.

Edwards, C. (1981). The Bases for Regional Growth: A Review. In L. R. Martin (Ed.), $A$ Survey of Agricultural Economics Literature (Vol. 3, pp. 159-282). Minneapolis, MN: University of Minnesota Press.

Haggblade, S., Hazell, P., \& Reardon, T. (2010). The Rural Non-Farm Economy: Prospects for Growth and Poverty Reduction. World Development, 38, 1429-1441. https://doi.org/10.1016/j.worlddev.2009.06.008

Harrison, W. J., \& Pearson, K. R. (1996). Computing Solutions for Large General Equilibrium Models Using GEMPACK. Computational Economics, 9, 83-127. https://doi.org/10.1007/BF00123638

Hertel, T. W. (1997). Global Trade Analysis: Modeling and Applications. Cambridge: Cambridge University Press.

Leontief, W. (1936). Quantitative Input and Output Relations in the Economic Systems of the United States. The Review of Economics and Statistics, 18, 105-125.

Leontoef, W. (1941). The Structure of the American Economy 1919-1939: An Empirical Application of Equilibrium Analysis. Cambridge: Cambridge University Press.

Leontief, W. (1953). Studies in the Structure of the American Economy. New York: Oxford University Press.

Leontief, W. (1985). Why Economics Needs Input-Output Analysis. Challenge, 28, 27-35.

Irwin, E. G., Isserman, A. M., Kilkenny, M., \& Partridge, M. D. (2010). A Century of Research on Rural Development and Regional Issues. American Journal of Agricultural Economics, 92, 522-553. https://doi.org/10.1093/ajae/aaq008

Lin, H. C., Lee, H. L., Hsu, S. M., Lin, K. J., Lee, D. H., Chang, C. C., \& Hsu, S. H. (2015). Baseline Forecasting for Taiwan's Population in the Face of Low Fertility Rate and Ageing Problems. Taiwan Economic Forecast and Policy, 46, 113-156.

Lin, K. J., Hsu, S. M., \& Hsu, S. H. (2013). An Economy-Wide Analysis of Impacts on Taiwan's Labor Market and Income Distribution of Chinese Taipei-Chinese Mainland Economic Cooperation Framework Agreement (ECFA). Taiwan Economic Forecast and Policy, 44, 27-80.

Mishra, A. K., \& Sandretto, C. L. (2002). Stability of Farm Income and the Role of Nonfarm Income in U.S. Agriculture. Review of Agricultural Economics, 24, 208-221. https://doi.org/10.1111/1058-7195.00014

OECD (2016). Rural Policy 3.0. In OECD Regional Outlook 2016: Productive Regions for Inclusive Societies (pp. 179-222). Paris: OECD Publishing.

https://doi.org/10.1787/9789264260245-7-en

Reardon, T., Berdegué, J., \& Escobar, G. (2001). Rural Nonfarm Employment and Incomes in Latin America: Overview and Policy Implications. World Development, 29, 395-409. https://doi.org/10.1016/S0305-750X(00)00112-1 
Ruttan, V. W. (1955). The Impact of Urban-Industrial Development on Agriculture in the Tennessee Valley and the Southeast. Journal of Farm Economics, 37, 38-56.

https://doi.org/10.2307/1234073

Stabler, J. C., \& Olfert, R. (2009). One Hundred Years of Evolution in the Rural Economy. In J. M. Porter, \& C. Avery (Eds.), Perspectives of Saskatchewan (pp. 125-147). Winnipeg: University of Manitoba Press.

Tura, E. G., \& Assefa, B. (2017). Sources of Income Inequality among Farm Households in Ethiopia; Using of Gin Coefficient. American Based Research Journal, 6, 14-24. https://ssrn.com/abstract=3575486 